'Roneod' sheets bound in paper covers (London : Institute of Industrial Administration, 1933. 5s.). They are none the worse for this, and two of them deal in an effective manner with difficult problems of distribution, and another is on research in industry, by Mr. A. P. M. Fleming.

IN few branches of social study, however, is there a greater tendency to discursiveness and mere talk than in these various divisions of industrial administration, especially in salesmanship and advertising; and in fewer still is there a greater misuse of the term 'science'. In the papers here published it must be admitted that this tendency is little in evidence. They are indeed bright, brief and stimulating. The discursive tendency is perhaps exhibited most in the first paper on personal and impersonal management, by $\mathrm{H}$. N. Munro, although his theme, so far as it can be definitely apprehended, seems sound enough. The next two papers, on distribution, are well worth reading and serious reflection, not only because this subject is one of the most important and difficult in the present age, but also because the authors strongly condemn that 'production complex' which is still too much in evidence in industrial management. One of them, based largely on personal experience, has an air of convincing reality and logic which is very attractive. It is scarcely necessary to say that Mr. Fleming's paper on research is characterised by his usual methodical and orderly presentation, and overwhelming arguments in support of far-sighted research policies and carefully thought-out research programmes. Other papers deal with finance and secretarial duties.

\section{Flood and Erosion Control}

Among the various expedients put forward for dealing with the problem of unemployment in the United States, one of considerable interest from a scientific point of view is that of Dr. L. E. Freudenthal, chairman of the Institute of Irrigation Agriculture, American Farm Bureau Federation, Las Cruces, N.M. In an address to the South-Western Division of the American Association for the Advancement of Science, which appears in Science of November 17,1933 , he points out that flood and erosion control are matters of national importance in America in that they are beyond the capacities of individual States to deal with. He instances the huge sums of money which have been beneficially expended on water supply, irrigation, water power and waterway undertakings and the equally enormous losses of life and property due to floods and erosion. The Mississippi flood of 1927, which inundated 18,000 square miles, drove 750,000 persons from their homes, did some $300,000,000$ dollars worth of damage and took 246 lives, is, he states, an example of what is happening annually on a smaller scale in nearly every State. For the last twenty years, flood damage in South Carolina and Tennessee has averaged nearly one million dollars per annum.

THE attendant erosion of fertile lands is stated by Dr. Freudenthal to be a national menace and he quotes a report of the U.S. Bureau of Soils to the effect that not less than 126 billion pounds of plant food material is removed from the fields and pastures of the United States every year, the value of the plant food elements in the waste being $2 \frac{1}{2}$ billion dollars annually. Erosion, adds Dr. Freudenthal, has been the principal cause for abandoning millions of acres of cleared land, and he goes on to suggest various directions in which Government assistance might be rendered in the matter of flood control measures with the object of providing relief for unemployment, including stream regulation, tree and brush planting, contour furrowing, protective fencing and seeding. $\mathrm{He}$ believes that flood and erosion control work are ideally suited for unemployment relief, not only for the reasonably effective results which could be obtained, but also because of the possible excellent effect upon the unemployed themselves.

\section{Darwin's Parish}

Sir Buckston Brown's generous gift to the British Association, in trust as a national possession, of Down House, Charles Darwin's home for forty years, and his further benefaction of the Research Farm of the Royal College of Surgeons at Downe, have revived the association with science of a secluded Kentish village which has retained much of its rural character, although within twelve miles of Charing Cross. It is sometimes forgotten that Downe was the residence of the Lubbocks and that it was here that John Lubbock, afterwards the first Lord Avebury, entered into the close and lifelong friendship with Darwin which exercised so great an influence on his scientific work. It is only reasonable to expect that those who visit Down House, now that it has become a place of scientific pilgrimage, should wish to know more of the history of its village. This need has been met in a little book ("A History of Darwin's Parish : Downe, Kent", Russell and Co., Southern Counties Ltd., Southampton, pp. viii +88 . 1s. 6d.) written by Dr. O.J.R. Howarth, secretary of the British Association, and Mrs. Howarth, with a foreword by Sir Arthur Keith, now also a resident of Downe. The parish history has nothing sensational to relate; but apart from the association with Darwin, it is interesting as a record of the life of a typical secluded English village-a life, which as the authors allow us to see by their skilful selection from humdrum records, was not without its humours and its tragedies. The evidence, which, so far as written documents are concerned, begins about A.D. 1100 , is fragmentary at the best; but the authors have made the most of their material and have produced a really informative and in. teresting account of the parish.

\section{Psychology in Germany}

The German Psychological Association's proceedings at its thirteenth congress, held at Leipzig on October 15-19, are reviewed in a thoughtful article, "Psychology under Hitler" by Goodwin Watson of Columbia University, in School and Society of 